\title{
THE CRIMINAL JUSTICE SYSTEM \\ IN SOVIET RUSSIA AND THE USSR (1917-1953): \\ EMERGENCE, DEVELOPMENT AND TRANSFER TO THE LITHUANIAN SSR
}

\author{
Monika Kareniauskaite
}

\begin{abstract}
The aim of the article is to analyse the Soviet definition of crime, the structure and logic of Soviet criminal law, and the system of criminal prosecution developed by the Bolsheviks after the October Revolution of 1917, consolidated during the NEP and collectivisation, and reformed by Stalin and Andrey Vyshinsky in the mid-1930s. The research also examines the impact that these concepts, ideas, institutions, legal norms and practices had on newly occupied Soviet colonies, focusing on the case of the LSSR. First of all, the research demonstrates that the main laws, institutions and actors in the Soviet criminal justice system which functioned until the mid-1950s without radical changes were invented and defined just after the Revolution, Civil War and NEP. Impacted by Marxist philosophy, by the traditional Russian peasant mentality and pre-revolutionary Bolshevik experiences, the early Bolshevik criminal justice system already had features which became crucial to the implementation of Stalinist mass repressions. For instance, the criminal code of the RSFSR defined a crime as any act or omission dangerous to the Soviet order and state, but not as an act or omission prohibited by lawthis was possible due to the 'principle of analogy'. The criminal code of 1926, based on Bolshevik legal norms from the period of the Revolution and the Russian Civil War, was not replaced during the legal reform of the mid-1930s. The very same system was transferred to the Lithuanian SSR after the occupation. Despite some institutional differences, the main features did not vary from that of the RSFSR, and the two were linked in the common system, the Russian one having hierarchical superiority. 'Union' laws prevailed over republican ones. But in the LSSR, the process of colonisation in the field of the criminal justice system was difficult, due to the strong armed anti-Soviet resistance, and the lack of well-educated and loyal Soviet legal personnel.
\end{abstract}




\section{Introduction}

The aim of the article is to investigate the nature and content of the legal concepts, ideas, institutions and criminal prosecution practices developed by the Bolsheviks in the period of the October Revolution and the Civil War. It examines the impact they had on the further evolution of the Soviet criminal justice system until the end of Stalinism, both at the centre of the Soviet empire (Soviet Russia $^{1}$ ) and on its peripheries (Soviet Lithuania ${ }^{2}$ ). The hypothesis of the analysis states that it was the Revolutionary and Civil War period rather than Stalinism that exerted a decisive impact on the further development of criminal law and the criminal justice system in the USSR.

In the contemporary legal and historical tradition, two definitions of the Soviet legal and criminal justice system exist: 1) it was more a tool of totalitarian power designed to carry out repressions and implement Bolshevik social engineering than a sui generis system; 2) Soviet criminal law and the model of the criminal justice system were designed as a separate legal sub-system, a part of so-called 'socialist law', together with the other sub-systems of it (such as, for instance, Soviet civil law). ${ }^{3}$

Studies by Peter H. Solomon Jr. and Nicolas Werth are examples of the tradition of the first type. They focus on repressive aspects of the Soviet criminal justice system. ${ }^{4}$ The competing discourse, on the contrary, takes the idea of the existence of Soviet law for granted, and therefore no longer questions its very existence, but focuses mainly on the content of Soviet law. Researchers such as Ivo Lappena ${ }^{5}$ and Harold J. Berman ${ }^{6}$ analyse legal definitions and concepts, paying less attention to penal practices.

${ }^{1}$ Later referred to as the RSFSR, or Russian Soviet Federative Socialist Republic.

${ }^{2}$ Later referred to as the LSSR, or Lithuanian Soviet Socialist Republic.

${ }^{3}$ A. Ostroukh, 'Russian Society and its Civil Codes: A Long Way to Civilian Civil Law', Journal of Civil Law Studies, vol. 6, Issue 1, summer (2013), p. 374.

${ }^{4}$ P.H. Solomon Jr., Soviet Criminal Justice under Stalin (Cambridge, 1996);

Н. Верт, Террор и безпорядок. Сталинизм как система (Москва, 2010).

${ }^{5}$ I. Lappena, Soviet Penal Policy (Denmark, 2000), last visited on 11 May 2016, http://www.ivolapenna.org/verkoj/books/soviet.pdf.

${ }^{6}$ H.J. Berman, 'Principles of Soviet Criminal Law', The Yale Law Journal, vol. 56, no 5, May (1947); Idem, Justice in the USSR. An Interpretation of Soviet Law (London, 1987). 
Both approaches, however, have limitations, which the research presented in the present article seeks to avoid. The first approach usually focuses only on political crimes and extra-judicial institutions, ${ }^{7}$ and forgets to take into account the usual system of courts and non-political criminality. The second approach deals mainly with the content of legal definitions and norms, thus remaining in the field of ideas, and in many cases ignoring their practical implementations. ${ }^{8}$

Seeking to avoid these limitations, the research design of the analysis, presented in this article, is formulated using a wider perspective. It is based on the research design strategy developed by the historian Paul R. Gregory. Though his main focus is on political repressions, the research is deeply contextualised, and the system of ordinary courts is not missed. ${ }^{9}$ Therefore, this article, as well, analyses the Bolshevik criminal justice system taking into consideration its repressive nature and the dimension of political crime. But also, an attempt has been made to reveal what lay beyond the horizon of repressions.

The methodology of the research is based on the following idea: the analysis of a certain criminal justice system must start from the definition of the concept of crime. To understand the general picture of the criminal justice mechanism, several aspects must be analysed: 1) law-making (the legal norms), 2) law-breaking (the actual crime in a concrete society and its functioning definition), 3) law-enforcement (the structure of institutional actors in the field of criminal justice and the sphere of criminal prosecution). ${ }^{10}$ Also, taking into consideration the specific structure of the Soviet legal system where the legal theory may have varied from legal norms, ${ }^{11}$ the research is divided into four levels:

a) The ideological level and the legal theory, the Bolshevik criminological discourse and Bolshevik definition of the categories of 'law' and 'crime'.

${ }^{7}$ As, for instance: Сталинизм в советской провинции: 1937-1938 г2. Массовая операция на основе приказа № 00447, сост. М. Юнге, Б. Бонвеч, Р. Биннер, (Москва, 2009).

${ }^{8}$ G.C. Guins, Soviet Law and Soviet Society (The Hague, 1954), p. 1.

${ }^{9}$ P.R. Gregory, Terror by Quota: State Security from Lenin to Stalin (London, 2009), p. 17.

${ }^{10}$ R.L. Akers, Criminological Theories: Introduction and Evaluation (London, 1999), p. 2.

${ }^{11}$ Berman, 'Principles of Soviet Criminal Law', p. 803. 
b) The level of legislation, or the field of criminal laws and norms.

c) The institutional level of criminal prosecution, or the field of actors responsible for dealing with crime in the Soviet system.

d) The level of practice in law enforcement and law breaking, or the process of criminal prosecution and criminal practices in society.

Thus, the article investigates how Bolshevik concepts of crime and law were defined and functioned at all levels at the centre of the USSR (the RSFSR) and on its periphery (the LSSR) until the end of Stalinism.

\section{The crime in Soviet legal theory: from 'nihilism' to the 'restoration of law'}

According to Paul R. Gregory, the system of Soviet criminal justice 'was in place well before Stalin's one-man rule'. ${ }^{12}$ The birth of the Bolshevik understanding of crime and law was a result of combining three main factors: the traditional Russian social organisation and mentality, Bolshevik empirical experiences, and Marxist philosophy.

The traditional Russian social organisation and Orthodox law produced the concept of 'joint responsibility' (круговая порука), ${ }^{13}$ which was later reflected in Bolshevik law. In traditional Russian rural communities, all members were highly interdependent in the organisation of labour and other practices. ${ }^{14}$ The level of individ-

12 Gregory, Terror by Quota: State Security from Lenin to Stalin, p. 1.

13 This term literally means the 'circular surety', but is better translated as 'joint responsibility'. Though the concept and idea of joint responsibility impacted Bolshevik legal thought, and later legislation and legal practices, the term itself was not used by the Bolsheviks in legal theory and, later, legislation. See more in: G. Hosking, Rulers and victims: the Russians in the Soviet Union (London, 2006), p. 11.

${ }^{14}$ It is important to stress that krugovaia poruka was a concept shaping the traditional mentality of the Russian Empire's rural areas, and a mechanism helping to collect and administrate taxes from peasants living in an obshchina (община). An obshchina was a village with communal ownership of land, governed by the full assembly of the community, called the skhod (cxod). Such collective responsibility was an important part of the everyday practices of traditional Russian rural communities, and therefore influenced their understanding about many different areas of social organisation and everyday life, including understanding of crime and guilt. This attitude, that the whole community shared responsibility for a crime by one individual, was well reflected by the Russian intelligentsia of the 19th century and by the intellectual discourse of this period, including, for instance, the novel The Brothers Karamazov by Fyodor Dostoyevsky (Федор Михайлович Достоевский). 
ualism was very low. In such conditions, all members of the community were understood as being responsible 'for settling conflicts, preventing crime, apprehending criminals', ${ }^{15}$ and the concepts of individual responsibility and personal guilt did not exist.

Next came Marxism, whose impact was also considerable. It formulated two principles embodied in Bolshevik criminological thought: a) crime is an outcome of social inequality, a way suppressed classes resist injustice; b) all existing forms of law are created by the upper social classes; therefore, the so-called 'capitalist' law must be replaced by the more just socialist law ${ }^{16}$ which was called by the Bolsheviks 'revolutionary law' (революиионные права) or 'Soviet law' (советское право). The terms themselves were used by the Bolsheviks in the early 1920s. They were embodied in works by Bolshevik legal thinkers, and were related to the institutionalisation of newly emerging Bolshevik law as an academic discipline. For instance, the Institute of Soviet Law was founded in 1922, and began to publish a journal called 'Soviet Law' (Советское право). A journal called 'The Revolution of Law' (Револючия права) was published at that time as well. ${ }^{17}$

However, 'joint responsibility' for a crime did not enter the legislation of the middle and second half of the 19th and the 20th century in the Russian Empire. 'Joint responsibility' for crimes did not exist in 'The Digest of Laws of the Russian Empire' (Свод законов Российской империи), the code of penal and civil law in Russian Empire, which functioned from 1835, and consisted of a collection of all valid laws of the Russian Empire, which were collected step by step in one book after 1803). 'Joint responsibility' was also not a part of the later codification by the Penal Code of the Russian Empire of 1846 (which was influenced by West European legal theory), and penal regulations of 1864 and 1869. The Criminal Statute of the Russian Empire of 1903 (which later became the basis of criminal law for independent Lithuania in 1918-1940) also included only the concept of individual guilt; no collective guilt was possible according to it. So 'joint responsibility' for a crime only appeared in Bolshevik penal law and penal practices, but was not inherited directly from the law of the Russian Empire. See more in: V. Andriulis, M. Maksimaitis, V. Pakalniškis, J.S. Pečkaitis, A. Šenavičius, Lietuvos teisès istorija (Vilnius, 2002), pp. 274-278, 405-409.

${ }^{15}$ Hosking, Rulers and victims: the Russians in the Soviet Union, p. 11.

${ }^{16}$ The term 'socialist law' is a general concept used by contemporary legal historians and legal scholars to describe the legal tradition based on Marxism and Leninism, and formulated in Soviet Russia and the Soviet Union after the October Revolution of 1917. Bolsheviks of that period used other terms more: 'revolutionary law', 'Soviet law'. See more in: M.A. Glendon, M.W. Gordon, C. Osakwe, Vakaru teisès tradicijos (Vilnius, 1993), pp. 258-266.

${ }^{17}$ B. Bowring, Law, Rights and Ideology in Russia. Landmarks in the Destiny of a Great Power (New York, 2013), pp. 55-57. 
According to the Bolshevik legal theory of that time, even socialist law is needed only during the period of social transformation. There will be no need for law in communism, because no crime will exist there, due to the equal division of resources. ${ }^{18}$

Hence, the Bolshevik understanding of crime and law was influenced by the so-called Marxist 'legal nihilism'. ${ }^{19}$ Bolshevik ideology claimed that a society without crime is not only possible but unavoidable in communism. ${ }^{20}$ This attitude after the Revolution led the Bolsheviks to a total rejection of the previous legal order, and to the creation of new 'socialist' law. It had to be not only fairer and protect the rights of the proletariat better, but it had to serve as a temporary tool to deal with crime during the period of social transformation to a communist society.

The third aspect of the Bolshevik attitude towards law and crime was related to their own experience of being an underground organisation, whose members were persecuted by the law of the Russian Empire (and some were even linked with non-political criminal networks). ${ }^{21}$ Lenin also "perceived "traditional criminals" as potential allies'. Enemies of the Revolution, on the contrary, were perceived as dangerous criminals. These factors later determined one of the main features of the Soviet criminal justice system: a sharp distinction between two categories of crimes, 'political' and 'criminal'. The first were hardly persecuted. In the case of ordinary crimes, Lenin believed, that 'the Revolution itself would do away with them'; therefore, the Bolshevik regime had to devote less attention to them. ${ }^{22}$

This attitude, Lenin's indulgence towards so-called 'traditional criminals', is well expressed in Lenin's text written on 24 to 27 December 1917 (6 to 9 January 1918), and called 'How to Organise Socialist Emulation'. ${ }^{23}$ While Lenin expresses the idea of 'dire

${ }^{18}$ J.R. Lilly, F.T. Cullen, R.A. Ball, Criminological Theory: Context and Consequences (California, 2011), p. 167.

${ }^{19}$ The concept 'legal nihilism' is used by legal scholars and historians to describe the Marxist, Bolshevik and Leninist attitude towards the law; but this term did not occur in Bolshevik legal thought and legal doctrine. See more in: Lappena, Soviet Penal Policy, p. 11.

${ }^{20}$ Berman, 'Principles of Soviet Criminal Law', pp. 803-804.

${ }^{21}$ S. Sebag Montefiore, Der Junge Stalin (Frankfurt am Main, 2007), p. 17.

${ }^{22}$ A. Applebaum, GULAG. A History (New York, 2003), pp. 5-6.

23 'Socialist emulation' (in Russian сочиалистическое соревнование) was a form of competition between state enterprises and between individual workers in the USSR. It was a tool widely used by Soviet propaganda, especially in the period of industrialisation. 
war against the rich', against the 'bourgeois intelligentsia', 'frauds', 'drones' and 'hooligans', he also states that in unjust capitalist societies 'thousands' of not rich, lower class people 'were forced into the way of hooliganism, selling themselves and becoming frauds due to misery and poverty'. According to Lenin, in such unjust societies 'human beings were losing their human shape'. ${ }^{24}$ So Lenin expresses clearly the idea that an unjust capitalist system can force even workers and peasants into a criminal lifestyle, but these criminals are treated as less dangerous, because the main reason for their crimes is capitalism, together with the rich social classes who support and maintain the capitalist system.

The legal theory developed in Bolshevik ideology dominated after the Revolution and continued until the mid-1930s. The Marxist nihilist attitude still existed during the New Economic Policy (NEP), even though the relatively softer character of the regime created conditions to develop a certain amount of theoretical pluralism. As mentioned before, during the NEP, Bolshevik law existing at the level of ideology was transferred to the discipline of professional law, and even some legal academic journals dedicated to the new Soviet law were published. However, all these journals were part of Marxism. ${ }^{25}$

Changes in Soviet legal theory took place when 'legal nihilism' lost its ideological background, due to Stalin's announcement of the creation of socialism in one country in 1936. The idea that law would soon be abolished was replaced with a new statement alleging that there was a need for legal stability. This reform is defined by the legal historian H.J. Berman as the 'Restoration of Law'. ${ }^{26}$

The reform was related to the general change in Soviet ideology. In 1936, the creation of a classless society in the USSR was announced, 'socialism in one state' was recognised as a possible reality. The same year, Stalin declared that the stability of the law was needed now more than ever in the past. ${ }^{27}$

${ }^{24}$ V. Leninas, 'Kaip organizuoti lenktyniavimą?'; V. Leninas, Pilnas raštu rinkinys, t. 35 (Vilnius, 1986), p. 198.

${ }^{25}$ Bowring, Law, Rights and Ideology in Russia. Landmarks in the Destiny of a Great Power, pp. 55-57.

${ }^{26}$ Berman, Justice in the USSR. An Interpretation of Soviet Law, pp. 29-66.

${ }^{27}$ Ibid., pp. 53-55. 
The leading jurist and architect of the reform was Andrey Vyshinsky (Андрей Януарьевич Вышинский). ${ }^{28}$ With Stalin's approval, he managed to develop a separate legal theory, where law was separated from politics and economics, and became an independent doctrine. Contrary to his predecessors, Vyshinsky stated that the highest level of the development of law was reached not in capitalism, but in socialism in one state. ${ }^{29}$ Thus, he developed a legal theory of positivism in place of that of nihilism. This change was determined by two reasons: the practical need for law in a society where criminality, contrary to the Marxist thesis discussed, did not decline even after socialism had been established; and Stalin's attempts to justify the Great Purge. ${ }^{30}$

Another change of the period was that the traditional Bolshevik distinction between a political and 'normal' crime was sometimes obliterated. For instance, charges of embezzlement of the state's property during that period could be formulated as both 'criminal' and 'political' crimes. ${ }^{31}$

Until the end of Stalinism, Soviet Lithuania did not have any separate legal theory or doctrine. It adopted the ideological clichés and dominant trends of the USSR. It took up the idea of the criminal nature of the wealthy classes and the bourgeoisie, and the poor peasants and workers committing crimes only because they were suppressed by higher social elites and could not survive otherwise.

De-humanising rhetorical forms were used to describe social groups understood now as 'enemies' and 'political criminals', repeating the ideological clichés of revolutionary Russia. In the ideological context and the public discourse, political criminals were depicted, first of all, as social parasites. Their negative role in the state institutions of Soviet Lithuania was emphasised. This propaganda campaign and criminological rhetoric was, as a rule, directed against concrete target groups, which were to be repressed soon, first of all, the former elites and employees of the former legal and criminal justice systems. The former 'bourgeois' authority and

${ }^{28}$ F.J. Feldbrugge, 'Soviet Criminal Law. The Last Six Years', The Journal of Criminal Law, Criminology and Police Science, vol. 54, no. 3 (September, 1963), pp. 261-262.

${ }^{29}$ Berman, Justice in the USSR. An Interpretation of Soviet Law, pp. 54-55.

${ }^{30}$ R. Pipes, Russia under the Bolshevik Regime (New York, 1995), pp. 402-403.

${ }^{31}$ Berman, Justice in the USSR. An Interpretation of Soviet Law, pp. 56-57, $60-63,66$. 
institutions were depicted as criminal structures, ${ }^{32}$ their employees as 'criminals' and 'exploiters'. ${ }^{33}$

Also, former members of political parties in the LSSR after the occupation of 1940 were defined by the term 'enemies of the people'. ${ }^{34}$ Various terms of criminological discourse, such as 'gang', were used. ${ }^{35}$ Not only the former elite, but the whole independent Republic of Lithuania of 1918-1940 was depicted as a state of criminals, where corruption, bribery and theft flourished. ${ }^{36}$ These tendencies repeated the Marxist and Bolshevik idea that crime was produced by the unjust capitalist system, and would disappear in communism. And that the main task of the socialist state was to fight political crime, which was linked first of all to the criminalisation of former elites and real or imagined political opposition.

\section{The nature of legislation: Bolshevik. Stalinist? Peripheral?}

Despite theoretical legal nihilism, the Bolsheviks started developing their criminal justice system during the period of the Revolution and the Civil War. ${ }^{37}$ The first document which officially defined crime in Soviet Russia was called 'The Guiding Principles of Criminal Law of the RSFSR' Руководящие начала по уголовному npaвy PСФСР), ${ }^{38}$ and was issued on 12 December 1919 by the People's Commissar for Justice. According to this document, two drafts, which tried to formulate the nature of the penal code, were prepared, in 1920 and 1921. The first Criminal Code of Soviet Russia was issued in $1922 .{ }^{39}$

After the Revolution and the Civil War, the Bolshevik state was concerned with transferring their newly invented legal principles to the other Union Republics. The decree 'On the Fundamental Princi-

${ }^{32}$ A. Maginskas, 'Tegyvuoja 13-oji Lietuvos socialistinè sovietų respublika. Vilniečiu mitingas', Tiesa, 194007 01, No 10, p. 3.

33 'Ir gen. Plechavičius pabėgo', Liaudies balsas, 194006 24, No 4, p. 3.

${ }^{34}$ Z. Genys, 'Komunistų partija legali!', Tiesa, 194006 26, No 6, p. 2.

35 'Šalin smetoniška gauja iš mūsų tarpo', Tiesa, 194006 28, No 8, p. 3.

${ }^{36}$ V. Rudminas, 'Grąžinti liaudžiai, kas iš jos yra pavogta', Tiesa, 19400702 , No 11, p. 2.

${ }^{37}$ Solomon, Soviet Criminal Justice under Stalin, p. 19.

${ }^{38}$ The Guiding Principles of Criminal Law of the RSFSR, last visited on 15 June 2016, http://soviethistory.msu.edu/1917-2/state-security/state-security-texts/ guiding-principles-of-criminal-law-in-the-rsfsr/.

${ }^{39}$ Lappena, Soviet Penal Policy, pp. 27-28. 
ples of Criminal Legislation of the USSR and the Union-Republics' (Основные начала уголовного законодательства Союза ССР и Союзных Республик) ${ }^{40}$ of the Central Executive Committee of the USSR, of 31 October 1924, described the new principles of criminal law. The criminal codes of other republics had to conform to them. One more criminal code of the RSFSR was issued in 1926, and came into force in 1927. The criminal codes of other Republics of the Soviet Union were adopted during the period 1926 to 1928. They had the structure of the Soviet legal system. ${ }^{41}$ Thus, Bolshevik legal principles became obligatory legal principles all over the Soviet empire.

According to Johan Bäckman, 'in Russia, the criminal code' is designed so that it 'dissolves the border between actual crime and any activities contradicting state interests'. ${ }^{42}$ The 'Guiding Principles' of 1919 embodied one of the basic Bolshevik legal principles, the so-called 'material definition of crime', which defined crime 'as an action or omission, dangerous for a given system of social relationships'. This means that not only actions or omissions, written in the law, can be defined as crimes, but also every other act, even not written in the criminal code, if it is recognised as dangerous to the Bolshevik state. ${ }^{43}$ This definition also determined another feature of the Soviet criminal justice system: crime against the state was much more important than crime against the individual.

The 'material definition of crime' could exist in Soviet legislation because one of the guiding rules of Western legal systems, the maxim nullum crimen sine lege (no crime without law), was not adopted in the Criminal Code of $1922 .{ }^{44}$ That created the theoretical possibility for the criminal prosecution of acts which are not identified in Soviet law, without violating Soviet legal procedures and misusing the law. The criminal code itself was designed so that it

${ }^{40}$ Основные начала уголовного законодательства Союза ССР и Союзных Республик, last visited on 15 June 2016, http://www.libussr.ru/doc_ussr/ussr_2237.htm.

${ }^{41}$ Ibid., pp. $28-34$.

42 J. Bäckman, 'The Hyperbola of Russian Crime and the Police Culture', Economic Crime in Russia, A.V. Ledeneva, M. Kurkchiyan (eds.) (The Hague, London, Boston, 2000), p. 260.

${ }^{43}$ Lappena, Soviet Penal Policy, pp. 27-28.

44 Ibid., p. 28. 
should prohibit not a concrete list of crimes but every act that was potentially dangerous to the Soviet order, which could be labelled as such by the totalitarian authority. ${ }^{45}$

The 'material definition of crime' became one of the most important traits defining crime in the USSR. It was transferred into all later criminal codes of the RSFSR and other Soviet Republics issued before the end of Stalinism. ${ }^{46}$ It also opened the door to applying the 'principle of analogy' in the process of criminal prosecution: if an act was recognised as harmful to the Soviet state but was not defined in the Criminal Code, another similar law could be applied. ${ }^{47}$ Article Number 16 of the RSFSR Criminal Code of 1926, which after the Soviet occupation of 1940 was applied to Lithuania, embodied the principle of analogy, and claimed that 'If some action dangerous to society is not involved directly in this Code, the basis and limits of responsibility for it are set by applying these articles of the Code, which cover crimes of the most similar sort. ${ }^{48}$

The principle of the 'material definition of crime' was embodied in Article $58^{49}$ of the Soviet Criminal Code. According to Alexander Solzhenitsyn, the open and ambiguous formulation of its paragraphs, flexibility and dialectical way of application created the theoretical possibility for the criminalisation of almost every action, if it was recognised as dangerous to the Soviet state. ${ }^{50}$

According to J. Bäckman, the Soviet concept of crime accentuates the 'socially dangerous' consequences of an act (consequences which are at variance with state interests), rather than the guilt of

${ }^{45}$ A.K.R. Kiralfy, 'Recent Legal Changes in the USSR', Soviet Studies, vol. 9, no 1, July, (1957), p. 14.

46 Уголовный кодекс РСФСР: с изменениями на 1 декабря 1938 г.: офиииальный текст с приложением постатейно-систематических материалов (Москва, 1940).

${ }^{47}$ Lappena, Soviet Penal Policy, pp. 31-34.

48 'If any actiondangerous to society is not directly described by this Code, the basis and limits of liability for the action are determined by applying those articles of the Code which define the most similar kinds of crimes', RTFSR baudžiamasis kodeksas su pakeitimais iki 1940 m. lapkričio 15 d. (Kaunas, 1941), p. 16.

${ }^{49}$ Article 58 of the Russian SFSR Penal Code came into force on 25 February 1927, and was revised several times, the most in 1934. But its conditions were created by early Bolshevik legislation.

${ }^{50}$ A. Solženycinas, Gulago archipelagas, t. 1 (Vilnius, 2009), p. 75. 
the suspect. ${ }^{51}$ Therefore the first Bolshevik Criminal Code did not include the concept of 'individual guilt'. ${ }^{52}$ Also, the principle of collective responsibility rooted in the concept of 'joint responsibility' was embodied in Soviet criminal law. ${ }^{53}$ There, the reason to punish an individual was not seen in the evidence of 'guilt', but in labelling an individual as 'socially dangerous', usually due to his or her group belonging. ${ }^{54}$ Hence, in Bolshevik legislation, 'the concept of guilt' was supplemented with 'the danger of personality'. ${ }^{55}$

Soviet criminal law also permitted applying Soviet laws to activities committed when those laws were not yet adopted. ${ }^{56}$ So Soviet law did not include the principle lex retro non agit (the law does not operate retroactively). ${ }^{57}$

This logic allowed for the criminal prosecution of entire groups, for example, the so-called byvshie liudi (бывшие люди) the former 'ruling classes', real or imaginary enemies of the revolution. ${ }^{58}$

The term byvshie liudi came from the early years of Bolshevik rule, the show trials against $\mathrm{SRs}^{59}$ in the summer of 1921. The show trials came together with a big hatred propaganda campaign. During it, Anatoly Vasilyevich Lunacharsky (Анатолий Васильевич Луначарский), who was one of the prosecutors of that time, labelled defendants as 'vermin' and 'germs' that could infect the entire population. In 1922, he also wrote a pamphlet called 'Former People', and thus the term came into Bolshevik ideology and terminology. But the term was originally used for the first time in a short story of the same name by Maxim Gorky (Максим Горький), which

${ }^{51}$ Bäckman, The Hyperbola of Russian Crime and the Police Culture, p. 261.

52 Applebaum, GULAG. A History, p. 5.

${ }^{53}$ G. Šapoka, 'Sovietinès Lietuvos baudžiamosios teisès vertinimas lietuvių teisininkų išeivių darbuose', Jurisprudencija, no 18 (2), (2011), p. 461.

${ }^{54}$ L. Viola, 'The Second Coming: Class Enemies in the Soviet Countryside, 1927-1935', Stalinist Terror. New Perspectives, J.A. Getty, R.T. Manning (eds.) (Cambridge, 1993), p. 70.

${ }^{55}$ Bäckman, The Hyperbola of Russian Crime and the Police Culture, p. 261.

56 Šapoka, 'Sovietinès Lietuvos baudžiamosios teisès vertinimas lietuvių teisininkų išeivių darbuose', p. 461.

${ }^{57}$ D. Indrišionis, 'Mirties bausmė Lietuvos SSR 1950-1990 m.: teisiniai pagrindai ir periodizacija', Genocidas ir Rezistencija, no 1(39) (2016), p. 70.

58 Viola, The Second Coming: Class Enemies in the Soviet Countryside, 1927-1935, p. 70.

59 'The Socialist Revolutionary Party' (Russian: Партия социалистов-революиионеров, ПСР). 
was published in $1903 .{ }^{60}$ In this way, the meaning of the concept 'criminal' was linked with the image of an enemy.

Hence, the Criminal Code of 1926, the one which, after the occupation, also functioned in Soviet Lithuanian, defined a crime as an action or omission 'dangerous to society', or 'every action or omission directed against the Soviet order or violating the legal order, established by the authority of Peasants and Workers for the period of transition to the communist system'. ${ }^{61}$

It is also important to mention that the principle of 'joint responsibility' did not remain in Soviet legal theory or practice only, the Criminal Code also involved elements of it as well. As an example, the famous 58th Article (section 581c) can be mentioned, which stated:

... when a soldier escapes or flees abroad, adult members of his family, if they by some means helped to carry out or to prepare the treason, or if they at least knew about it, but did not inform the authorities, will be punished with imprisonment from five to ten years, and the confiscation of all their property. Other adult family members who lived together with the traitor or were supported by him materially when the crime was committed will be deprived of their electoral rights, and they will be deported to distant regions of Siberia. ${ }^{62}$

So, according to the logic of krugovaia poruka, family members were defined as responsible for a crime, even if they did not know anything about the planned or committed treason.

The 'restoration of law' reform did not bring about any significant changes in Soviet penal legislation. Of course, some less significant changes took place. For example, some new non-political activities, such as juvenile delinquency and abortion, were criminalised. ${ }^{63}$

${ }^{60}$ B.G. Rosenthal, New Myth, New World: From Nietzsche to Stalinism (Pennsylvania, 2002), p. 175.

61 'Any action or omission of such is recognised as dangerous to society if it is directed against the Soviet system or violates its legal order, which is established by the authority of workers and peasants for the period of transition to communism', RTFSR baudžiamasis kodeksas su pakeitimais iki 1940 m. lapkričio 15 d., p. 12.

62 'In the event of a soldier's desertation or defection abroad, any of-age family members who have assisted in the planned or executed disloyalty, or had any knowledge of it but did not inform the government, are punishable with imprisonment from five to ten years and confiscation of all their property. Other of-age family members of the disloyal person, as well as any dependants who lived with him at the time of the crime, lose their right to vote and are to be deported for five years to the distant regions of Siberia', RSFSR Criminal Code with amendments prior to November 15, 1940, p. 36.

${ }^{63}$ Berman, Justice in the USSR. An Interpretation of Soviet Law, pp. 48-49. 
However, even Stalin's growing cautiousness about the application of legal procedures during the process of criminal prosecution, investigation and trial did not lead him to issue a new criminal code. The code of 1926 remained in effect, which, as discussed above, was actually just an adaptation of the Bolshevik legislation of 1919. It means that no new codification was made by Stalin's and Vyshinsky's reform in the field of criminal law. Therefore, the conclusion can be drawn that the old Bolshevik criminal law was suitable to the new goals set by the Stalinist regime: to deal with imaginary political crimes without violating Soviet law and legal procedures. ${ }^{64}$

When Stalin's Constitution was published in 1936, no new legislation came in in the field of criminal law, except for some separate laws relating to the already-existing code of 1926. The existing legal order was simply strengthened even more, including the principle of imperial domination. Even more centralisation and less individualism for the Republics was declared by Article No 20 of the Constitution: 'In the event of a discrepancy between the law of a Union Republic and an all-Union law, the all-Union law prevails. ${ }^{65}$ This was repeated by the Criminal Code of the RSFSR, which after the occupation of 1940 was introduced in Soviet Lithuania: 'All Union law, if it differs from the one adopted at the level of a certain Republic, has priority'. ${ }^{66}$

So the period of the Revolution and the Civil War can be regarded not only as the starting point of Soviet legislation. Concepts such as 'material definition of crime' and 'analogy' devised in Soviet legislation during that period were not changed until the 1960s. ${ }^{67}$

The described model of Soviet criminal law, designed as a consequence of the Bolshevik Revolution, became an example for

${ }^{64}$ I am talking now only from the perspective of Soviet law. Of course, from the point of view of international law, the Stalinist repressions cannot be denied as criminal acts.

65 'В случае расхождения закона Союзной республики с законом общесоюзным, действует общесоюзный закон.' Конституция (Основной закон) Союза Советских Социалистических Республик (утверждена постановлением Чрезвычайного VIII Съезда Советов Союза Советских Социалистических Республик от 5 декабря 1936 г.), last visited on 1 July 2016, <http://constitution. garant.ru/history/ussr-rsfsr/1936/red_1936/3958676/chapter/2/>.

${ }^{66}$ RTFSR baudžiamasis kodeksas su pakeitimais iki $1940 \mathrm{~m}$. lapkričio 15 d., p. 171.

${ }^{67}$ Bäckman, The Hyperbola of Russian Crime and the Police Culture, p. 261. 
the LSSR. After the Soviet occupation in 1940, one of the initial steps was the destruction of the Lithuanian legal system. Also, a new concept of crime started to be formulated: first of all, at the level of ideology, followed by legal theory and practice. ${ }^{68}$ Books of Soviet propaganda published in the LSSR proclaimed that the main function of the court and the law was 'the organisation of the fight against the people's enemies'. ${ }^{69}$

Some new laws were adopted. For instance, on 22 October 1940, a decree of the Supreme Court of the LSSR criminalising 'sabotage' and 'the destruction of the state's property"70 was issued. On 1 December 1940, the Criminal Code of the RSFSR (of 1926) was adopted in the LSSR. This was done by the decree 'On the temporary application of criminal, civil and labour laws of the RSFSR in the territories of the Lithuanian, Latvian and Estonian Soviet Socialist Republics' from the Presidium of the Supreme Soviet of the USSR of 6 November 1940. It annulled all previous legislation and legal systems. ${ }^{71}$

The adopted criminal code transferred the material definition of crime and the principle of analogy to the LSSR. ${ }^{72}$ Although in the summer of 1941 Lithuania was occupied by Nazi Germany, that criminal code was re-established in 1944, and remained in effect until the 1960s.

\section{Institutional actors: formation, transformation, transfer}

Soon after the October Revolution, the system of institutions dealing with crime was established. The elimination of the Tsarist court system was one of the first steps the Bolsheviks took, by issuing the 'Decree of courts (No 1)' in 1917. The so-called 'local

${ }^{68}$ Lietuva 1940-1990. Okupuotos Lietuvos istorija, A. Anušauskas (ed.) (Vilnius, 2007), p. 96.

${ }^{69}$ I.D. Perlovas, Liaudies teismo darbo organizavimas (Kaunas, 1949), p. 3.

${ }^{70}$ M. Maksimaitis, S. Vansevičius, Lietuvos valstybès ir teisés istorija (Vilnius, 1997), pp. 227-228, 275; Šapoka, 'Sovietinès Lietuvos baudžiamosios teisès vertinimas lietuvių teisininkų išeivių darbuose', p. 459.

${ }^{71} \mathrm{~V}$. Žiemelis, 'Lietuvos prokuratūros pertvarkymo į sovietinę prokuratūrą raida 1940-1941 metais', Jurisprudencija, No. 12 (102), 2007, p. 17-19; Maksimaitis, Vansevičius, Lietuvos valstybès ir teisès istorija, p. 224.

${ }^{72}$ RTFSR Baudžiamasis kodeksas, veikiąs Lietuvos TSR teritorijoje (Vilnius, 1952), pp. 7-8; Maksimaitis, Vansevičius, Lietuvos valstybès ir teisès istorija, p. 275. 
mixed courts' were created. ${ }^{73}$ At the beginning, they functioned in a very chaotic way, and their names were different. ${ }^{74}$ The Bolsheviks also created special courts for political trials, revolutionary tribunals. ${ }^{75}$ Also, the People's Commissariat for Justice, the prototype of the Ministry of Justice of 1946, also called Narkomiust (Народный комиссариат юстиции, Наркомюст), was founded in 1917, for the purpose of managing courts. As of 1918 , it drafted new codes. ${ }^{76}$

Only supporters of the Revolution could work in the Bolshevik courts. As a rule, they had no legal education. New courts had hardly any independence, and they were under the control of the local authorities (Soviets). The main feature of their activities was the idea that 'where the law provided no guidance', judges had to rely upon their 'revolutionary consciousness', ${ }^{77}$ which was an empty and abstract concept. Therefore, the misuse of Bolshevik law became possible.

In 1919-1922, different courts were incorporated into one uniform, centralised and hierarchical system of People's Courts. They dealt with the majority of civil and criminal, as well as some administrative offences. Courts were of several levels: local, okrug ${ }^{78}$ (area), and oblast $^{79}$ (province, region) People's Courts and congresses. The appellations from the local People's Courts were forwarded to the courts of a higher level. The revolutionary tribunals were the

${ }^{73}$ G. Esakov, 'The Russian Criminal Jury: Recent Developments, Practice, and Current Problems', The American Journal of Comparative Law, vol. 60 (2012), p. 669.

${ }^{74}$ Solomon, Soviet Criminal Justice Under Stalin, p. 21.

75 Ibid., p. 20; Esakov, The Russian Criminal Jury: Recent Developments, Practice, and Current Problems, p. 669.

${ }^{76}$ Solomon, Soviet Criminal Justice Under Stalin, pp. 19-21.

${ }^{77}$ Ibid., p. 21.

${ }^{78}$ The term okrug (округ) was a type of Soviet administrative division. This tradition of administrative division was inherited from the Russiam Empire. In the 1920 s, okrugs were administrative divisions of several other primary divisions, such as oblasts, krais, and others. For some time in the 1920s, they also served as the primary unit when the guberniyas were abolished. At that time, okrugs divided into raions (район). On 30 July 1930, most of the okrugs were abolished.

${ }^{79}$ The term oblast (область) can be translated as 'area', 'zone' or 'province'. In the USSR, oblasts were a type of administrative division of Union Republics. Oblasts were composed of 'districts' (raions) and cities or towns. Cities and towns came directly under the jurisdiction of oblasts. Some oblasts also included autonomous entities, autonomous okrugs. 
highest level. ${ }^{80}$ In 1923, the Supreme Court of the Soviet Union was founded. The Military Collegium of the Supreme Court of the Soviet Union was created in 1924.

The new system of institutions had one of the main features of the Soviet criminal justice mechanism, the difference between ordinary courts and extra-judicial institutions. ${ }^{81}$ In 1917, the VChK, or Cheka (чрезвычайная комииссия, ЧК'), the 'All-Russian Emergency Commission for Combating Counter-Revolution and Sabotage', was founded. By late 1918, hundreds of Cheka committees had been created in various cities, in multiple administrative units of Soviet Russia. The Cheka gained the right to investigate, interrogate and punish people for committing counter-revolutionary crimes. But it dealt with non-political crimes too. ${ }^{82}$ Later, the institution was renamed the OGPU, NKVD, MVD and KGB. ${ }^{83}$ However, usually, but not in all cases, People's Courts were formed to deal with usual and extra-judicial institutions with political crimes. ${ }^{84}$ Also, the prototype for the famous OGPU and NKVD troikas was created in 1918. Later, when Stalin announced that kulaks (кулак) ${ }^{85}$ would be 'liquidated as a class', ${ }^{86}$ they became very important.

Another very important step was the creation and development of penitentiaries. New Soviet labour camps appeared during the years of the civil war. In 1920, the so-called First Camp of the Gulag was founded on the Solovetsky Islands. In 1921, there were 48 camps. In 1929, the Gulag system became even more important, due to Stalinist industrialisation. ${ }^{87}$

${ }^{80}$ Berman, Justice in the USSR. An Interpretation of Soviet Law, p. 31.

${ }^{81}$ G.P. Van den Berg, 'The Soviet Union and the Death Penalty', Soviet Studies, Vol. 35, No. 2, Apr., (1983), p. 154.

${ }^{82}$ Solomon, Soviet Criminal Justice under Stalin, pp. 19-20.

${ }^{83}$ Gregory, Terror by Quota: State Security from Lenin to Stalin, p. 1.

${ }^{84}$ Van den Berg, The Soviet Union and the Death Penalty, p. 157.

${ }^{85}$ The term 'kulak', used to describe the rich peasantry, was a term with its origins in the Russian Empire (Stolypin reform), but it gained a mass application in Bolshevik terminology. The label kulak was broadened in 1918 to include any peasant who resisted handing over grain to detachments from Moscow, while during the campaign for collectivisation, almost all criteria were blurred, and even middling or poor peasants could be repressed. In Lithuanian the term was translated as 'buožé'. Basically, the definition 'kulak' was associated with a political criminal and enemy, and became the next big target group of Soviet repressions after the campaign against the 'former people'.

${ }^{86}$ T. Snyder, Bloodlands: Europe between Hitler and Stalin (New York, 2010), pp. 25-26.

${ }^{87}$ Applebaum, GULAG. A History, pp. xvi, 5, 7, 18-20. 
In the 1930s, changes associated with Stalin's regime touched the institutions of the criminal justice system. The role of extra-judicial bodies was growing. In January 1930, the goal 'to liquidate the kulaks as a class' was declared, and normal legal procedures were suspended following the OGPU order. The 'troika' was established in every locality. It could issue rapid verdicts without any right of appeal. Troikas served as judges, juries and executioners. By Order No 00447 of the NKVD of 1937, NKVD troikas were created at the level of the republic, krai ${ }^{88}$ and oblast, for speedy and simplified trials. The role of the Military Collegium of the Supreme Court of the Soviet Union was also changed in the 1930s. As of June 1934, it was assigned the duty of hearing cases under Article 58. But the majority of cases under Article 58 were decided by troikas. ${ }^{89}$

Hence, collectivisation and the Great Purge assigned a bigger role to extra-judicial bodies. ${ }^{90}$ Another change was the creation of the Office of the Public Procurator of the USSR in 1936. According to the Soviet Constitution of 1936, the procurator exercised the highest degree of control over the proper execution of laws. ${ }^{91}$ Also, law schools were expanded in the 1930s, and more educated judges and lawyers joined the system. The quality of the application of legal procedures improved. ${ }^{92}$

Consequently, there were changes in the Stalinist period, and they were taken into account when the Soviet legal order was transferred to the newly occupied territories in the 1940s. However, the main features of the court system formulated shortly after the revolution remained. ${ }^{93}$ Stalin's constitution of 1936 defined the court system of the USSR: the Supreme Court of the USSR (Верховный Cyd $C$ CCP), the Supreme Courts of Republics (Верховныле Cydbl

${ }^{88}$ The term krai (край) means a type of geographical administrative division in the Russian Empire and in the RSFSR. It is very difficult to translate into English, due to its specific meaning, having no analogues in other states; therefore, in this text we will use not a translated version. Etymologically, the word is related to the verb кроить, which means 'to cut'. Historically, krais comprised vast territories located along the periphery of the Russian state, since the word krai also means border or edge. In English, the term is often translated as 'territory'.

${ }^{89}$ Snyder, Bloodlands: Europe between Hitler and Stalin, pp. 25-26, 78-87.

${ }^{90}$ Ibid.

${ }^{91}$ L.M. Surhone, M.T. Tennoe, S.F. Henssonow, Procurator General of the Soviet Union (Saarbrücken, 2011).

${ }^{92}$ Berman, Justice in the USSR. An Interpretation of Soviet Law, p. 57.

${ }^{93}$ Ibid. 
Республик), the 'Krai' (Край) and 'Oblast' (Область) Courts, the Courts of the Autonomous Republics (Автономные Республики) and Autonomous 'Oblasts' (Областей), Courts of Areas (Окружные), Special Courts of the USSR (Специальные), and People's Courts (Hародные суды) ${ }^{94}$

After Lithuania's occupation, first of all, the employees of courts and professional lawyers and judges of the independent Republic of Lithuania (1918-1940) were replaced by new employees, who were uneducated but loyal to the communist authorities. ${ }^{95}$ The Lithuanian court system was replaced by the Soviet court system. On 30 November 1940, the new decree 'On the Reform of the Judicial System of Lithuania' was issued by the Supreme Council of the LSSR. The Soviet system of courts was developed based on this decree: People's Courts and War tribunals. The Supreme Court of the LSSR, together with the Military Collegium, ${ }^{96}$ was founded.

The OSO (Special Council of the State Security Ministry, NKVD), founded to deal with political crimes, was especially active in the LSSR. It had the right to pass sentence on the accused in his or her absence. ${ }^{97}$ The Prosecutor's Office was adjusted to the new system. ${ }^{98}$

However, the Soviet system of courts was not fully transferred to occupied Lithuania. For instance, so-called 'district courts' (in Lithuanian apskričiu teismai), written into the constitution of

${ }^{94}$ Article Number 102: 'Правосудие в СССР осуществляется Верховным Судом СССР, Верховными Судами союзных республик, краевыми и областными судами, судами автономных республик и автономных областей, окружными судами, специальными судами СССР, создаваемыми по постановлению Верховного Совета СССР, народными судами.' Конституция (Основной закон) Союза Советских Сочиалистических Республик (утверждена постановлением Чрезвычайного VIII Съезда Советов Союза Советских Социалистических Республик от 5 декабря 1936 г.), Last visited on 1 July 2016, http://constitution. garant.ru/history/ussr-rsfsr/1936/red_1936/3958676/chapter/9/; Tarybu Socialistiniu Respubliku Sajungos Konstitucija (Pagrindinis ịstatymas). Su TSRS Aukščiausiosios Tarybos I, II, II IV ir VII sesiju priimtais pakeitimais ir papildymais (Kaunas, 1940), p. 19.

${ }^{95}$ Žiemelis, 'Lietuvos prokuratūros pertvarkymo ị sovietinę prokuratūrą raida 1940-1941 metais', p. 18.

${ }^{96}$ Maksimaitis, Vansevičius, Lietuvos valstybès ir teisés istorija, pp. 242-241.

${ }^{97}$ J. Starkauskas, Čekistinè kariuomene Lietuvoje 1944-1953 metais: NKVDMVD-MGB kariuomené partizaninio karo laikotarpiu (Vilnius, 1998), p. 387.

98 Žiemelis, 'Lietuvos prokuratūros pertvarkymo ị sovietinę prokuratūrą raida 1940-1941 metais', pp. 18-19. 
the Lithuanian SSR, ${ }^{99}$ were not found in Lithuania in the period 1940-1941. They were not created due to the lack of trustworthy personnel. Instead, the 'county courts' (in Lithuanian apygardu teismai) inherited from independent Lithuania of 1918-1940 continued to function (but were transformed and changed). ${ }^{100}$

Nor were these 'district courts', or the 'county courts', however, specified in the All-Union Constitution of $1936 .{ }^{101}$ So the existence of 'district courts' in the LSSR constitution, the absence of 'district courts' in the LSSR reality, and the continuing existence of 'county courts', was a unique feature of the LSSR court system, and therefore it differed from the general model and Soviet 'ideal type' of court network.

All LSSR courts, however, were linked in one hierarchical network of the whole Union, defined in the Soviet constitution. ${ }^{102}$ County courts functioned as courts of first instance to deal with 'counter-revolutionary' crimes and some economic crimes. Some civil cases came into their competence too. ${ }^{103}$

Soviet documents issued in the LSSR declared that the main task of the People's Courts was 'to protect the social and state structure of the USSR embodied in Stalin's Constitution, along with its economic system and socialist property'. The main function of the court and law was defined as 'the organisation of the fight against the people's enemies'. 104

During the second Soviet occupation, from 1944, some cases came within the competence of war tribunals. ${ }^{105}$ The process of rebuilding the Soviet court system in the LSSR was renewed and lasted until 1956.

${ }^{99}$ Lietuvos Tarybu Socialistinès Respublikos Konstitucija (Pagrindinis įstatymas). Su Lietuvos TSR Aukščiausiosios Tarybos II,III ir IV sesiju priimtais pakeitimais ir papildymais (Kaunas,1946), pp. 20-21.

${ }^{100}$ D. Sagatienè, Sovietiniai bendrosios kompetencijos teismai Lietuvoje 19401941 ir 1944-1953 metais. Daktaro disertacija (Vilnius, 2013), p. 50.

${ }^{101}$ Конституциия (Основной закон) Союза Советских Социалистических Республик (утверждена постановлением Чрезвычайного VIII Съезда Советов Союза Советских Социалистических Республик от 5 декабря 1936 г.), Last visited on 1 July 2016, http://constitution.garant.ru/history/ussr-rsfsr/1936/ red_1936/3958676/chapter/9/; Tarybu Socialistiniu Respubliku Sajungos Konstitucija (Pagrindinis įstatymas). Su TSRS Aukščiausiosios Tarybos I, II, II IV ir VII sesiju priimtais pakeitimais ir papildymais, p. 19.

102 Ibid.

${ }^{103}$ Sagatiené, Sovietiniai bendrosios kompetencijos teismai Lietuvoje 1940-1941 ir 1944-1953 metais, p. 50.

${ }^{104}$ Perlovas, Liaudies teismu darbo organizavimas, p. 3.

${ }^{105}$ Maksimaitis, Vansevičius, Lietuvos valstybès ir teisès istorija, p. 242. 
After the reoccupation in 1944, due to a lack of personnel, county courts were not re-established. ${ }^{106}$ But all other institutions created between 1940 and 1941 were restored. ${ }^{107}$

On 25 October 1944, the Council of People's Commissars of the Lithuanian SSR in Moscow issued the act 'On Renewing the Activities of the LSSR People's Commissariats and Central Institutions and Recruiting their Personnel'. According to it, the activities of the LSSR People's Commissariat for Justice and the Supreme Court of the LSSR were renewed. ${ }^{108}$ According to the plan, 136 People's Courts had to exist as the first instance courts, and the Supreme Court as the highest court, thus repeating the model of the USSR completely. ${ }^{109}$ But due to the lack of sufficient human resources and ongoing Lithuanian armed resistance, until the middle of 1945, only 43 People's Courts were formed. ${ }^{110}$ The majority of the judges did not even have a secondary education. In 1953, a system of 112 courts was introduced. The restoration of the Supreme Court was much faster. ${ }^{111}$

Between 1951 and 1953, attempts were made to create four 'oblast' courts in the LSSR (Vilnius, Kaunas, Šiauliai, Klaipeda) according to the USSR court model. These attempts failed, due to the lack of well-qualified judges. The courts were abolished in 1953 together with the changes in the administrative division of the LSSR, ${ }^{112}$ when all four oblasts of the LSSR were dissolved.

So some local particularities existed in the LSSR court system. However, Lithuanian SSR courts and other institutions in the field of the Soviet criminal justice system were not only created according to the Russian SFSR example; all these institutions, as described in the 1936 Constitution of the USSR, were involved in one system with the USSR, and controlled by the Centre of the Soviet empire.

${ }^{106}$ Sagatienè, Sovietiniai bendrosios kompetencijos teismai Lietuvoje 1940-1941 ir 1944-1953 metais, p. 50.

${ }^{107}$ Idem, 'Sovietinių teismų atkūrimas ir raida Lietuvoje 1944-1956 metais', Socialiniu Moksly Studijos /Societal Studies, no 5(1) (2013), p. 194.

${ }^{108}$ Ibid., p. 195.

${ }^{109}$ A. Liakas, Tarybiniai teismai Lietuvoje 1940-1960 metais. Tarybu Lietuvos valstybès ir teisès dvidešimtmetis (Vilnius, 1960), p. 234.

${ }^{110}$ The list of employees of the Peoples Courts, 1 June 1945, LYA, f. 1771, ap. 8 , b. $283,1.9-10$.

${ }^{111}$ Sagatiené, 'Sovietinių teismų atkūrimas ir raida Lietuvoje 1944-1956 metais', pp. 195-196, 198.

${ }^{112}$ Sagatienè, Sovietiniai bendrosios kompetencijos teismai Lietuvoje 1940-1941 ir 1944-1953 metais, pp. 50-51. 


\section{Practice: law enforcement, criminal prosecution and tendencies of criminal acts}

Although the Soviet court system and the mechanism for criminal prosecution were designed as an ideal way to deal with political crimes, the scale of non-political criminality was not ignored. According to Paul R. Gregory, the majority of arrests made 'by the state security agency were classified as political crimes', but 'in the early 1920s, between 1930 and 1936, and during the war, the attention of the "organs" was also focused on "other crimes".' From 1933 to 1952, the number of sentences carried out by the regular courts in the USSR was higher than that of the extra-judicial tribunals (except in 1937 and 1938). Hence, although the main mission of the Soviet criminal justice system was to carry out repressions, the criminal prosecution of non-political criminals existed. ${ }^{113}$

Until 1953, the criminal justice system in the LSSR was more similar to that of the RSFSR of the period of the Revolution and the Civil War, rather than that of the Stalinism period. It focused on political crimes.

During the first Soviet occupation (1940-1941), the Soviet authorities were concerned with consolidating their power; therefore, the criminalisation of the byvshie liudi took place first. In the 1940s, arrests of members of the former Lithuanian political and social elite started, many of them were shot, or deported to the Gulags. This was not an attempt to suppress real opposition: the communist elite of the LSSR did not have any knowledge of it at that time. ${ }^{114}$

During the period between 1940 and 1941, people were tried for the illegal violation of the state border, many cases were initiated against former policemen and the security staff of the Lithuanian state. At the beginning of a trial, all the arrested people were accused according to Article 58. Only in cases where no confession to a crime was obtained, the NKGB and NKVD investigators tried to apply other articles. ${ }^{115}$ This was possible because of the principle of analogy.

After Lithuania's reoccupation in 1944, the attention to political crimes continued. At the fourth plenary session of the Central Committee of the Communist Party of Lithuania, which took place on 27-30 December 1944, urgent inducements were declared to imprison

${ }^{113}$ Gregory, Terror by Quota: State Security from Lenin to Stalin, pp. 16-18, 23.

${ }^{114}$ A. Anušauskas, Teroras. 1940-1958 m. (Vilnius, 2012), pp. 26-27, 29.

${ }^{115}$ Ibid., pp. 41, 43. 
or even designate the death penalty for criminals 'acting against the Soviet state'. ${ }^{116}$ Educational and propaganda-orientated brochures from this period also define the fight against political criminality as the main task of the criminal justice system in the LSSR. ${ }^{117}$

However, in the postwar years, the concept of byvshie liudi was no longer broadly applied in criminal prosecution practice, and the labels 'fascist' and 'bourgeois nationalist' became more common. These two terms were a reflection of the postwar changes in Soviet ideology, whereby Nazi or fascist was a definition of the enemy. Also, in 1947, mass collectivisation, alongside deportations and arrests of 'kulaks', started in the LSSR. 'Fascist' and 'bourgeois nationalist' were definitions of the Lithuanian armed resistance too. Its members and supporters accounted for a large number of political arrests and trials. ${ }^{118}$

However, the concept of byvshie liudi was sometimes used as an argument in the cases of people who were arrested for other reasons. For example, in the case of the Catholic Bishop Vincentas Borisevičius, who was accused according to Article 58 of being a supporter of the armed resistance, the logic of byvshie liudi was used together with other 'evidence' of guilt: during the investigation, he was asked about his activities in an organisation which operated more than two decades ago. ${ }^{119}$ This means that in 1946, past activities (carried out when Soviet legislation did not exist in Lithuania) were still used as a tool for criminalisation.

In the case of kulaks, as in Russia, the following logic described by A. Applebaum was applied in Lithuania: 'People were to be sentenced not for what they had done, but for what they were', even if 'nobody ever provided a clear description of what, exactly, a class enemy was supposed to look like. ${ }^{120}$ Hence, the criteria for

116 Lietuvos Komunistu Partijos (bolševiku) Centro Komiteto IV plenumas. 1944 m. gruodžio 27-30 d., (Vilnius, 1945), pp. 71, 75, 78.

117 D. Žuravliovas, Agitatorius - socialistinio lenktyniavimo organizatorius (Vilnius, 1948); L. Slepovas, Partinio gyvenimo nušvietimas laikraščiuose. Apie kai kuriuos bolševikinès spaudos uždavinius. Paskaitu, skaitytu respublikiniu kraštu ir sričiu laikraščiu redaktoriu pasitarime prie VKP(b) CK Propagandos ir agitacijos valdybos sutrumpintos stenogramos (Vilnius, 1947).

${ }^{118}$ Lithuania in 1940-1991: the History of Occupied Lithuania, A. Anušauskas (ed.) (Vilnius, 2015), pp. 245-308.

119 'Copy of the original criminal case of Bishop Vincentas Borisevičius', Lietuvos vyskupai sovietiniame teisme (Vilnius, 2000), pp. 37, 43.

${ }^{120}$ Applebaum, GULAG. A History, p. 6. 
establishing which farmer was rich enough to be regarded as a kulak varied. Deportations of kulaks in the LSSR were organised according to the pattern developed in Russia during the period of collectivisation: according to lists, by extra-judicial means. The uncertainty as to who the 'kulak' really was was similar to that in Russia in the late 1920s and the early 1930s. ${ }^{121}$ Many relatives of deportees and arrested people during that period did not understand the logic of the Soviet concept of crime, why their beloved ones, not rich, only 'average village farmers', were criminalised and punished. ${ }^{122}$ Or why that fate, being arrested, tried or deported 'as criminals', befell even those who had 'never belonged to any parties' and 'did not have real estate or land'. ${ }^{123}$ Citizens sent complaints about the injustice of the situation to the institutions of LSSR. ${ }^{124}$ These cases illustrate that deportations were carried out by quota, chaotically, without clear criteria for criminalisation.

However, due to the real armed opposition, which was defeated only in 1953, ${ }^{125}$ in many cases people were arrested for real rather than imaginary crimes ${ }^{126}$ in the LSSR. Such was the case of Povilas Buzas, who really was a member of the armed resistance. In 1946 he was accused according to Article 58 of participating in an 'armed gang of bourgeois nationalists'. ${ }^{127}$ However, in this case, one feature of the 'Stalin-Vyshinsky' reform period was also applied: the eliminated difference between a 'political' and 'criminal' crime. Buzas was accused not only of taking part in the armed resistance, but also of 'robbery of a Soviet farm'. This crime was not real, and Buzas categorically denied it (he confessed all the rest). ${ }^{128}$ Hence, Buzas' case also illustrates that some traits of the Stalinist reform of the 1930s in the field of legal practice were adopted in the LSSR.

${ }^{121}$ Compare, for instance: O. Adamova-Sliozberg, My journey: how one woman survived Stalin's gulag (Illinois, 2011), pp. 5-6.

${ }^{122}$ Deportation file, LYA, f. V-5, ap. 1, b. 24655, 1. 74.

${ }^{123}$ Deportation file, ibid., b. 41525, 1. 2, 2 a.p.

${ }^{124}$ Deportation file, ibid., b. 21504, 1. 54, 64.

${ }^{125}$ Lithuania in 1940-1991: the History of Occupied Lithuania, pp. 270, 285.

${ }^{126}$ However, it is important to bear in mind that the Lithuanian armed resistance was a crime according to Soviet law, but not according to international law. See more in: B. Gailius, Partizanai tada ir šiandien (Vilnius, 2006).

127 The criminal file of Povilas Buzas, LYA, f. K-1, ap. 58, b. 14141, t. 4, 1. $17-18$.

128 Ibid. 
So, in the LSSR, as in Soviet Russia, before the Second World War, the definitions of an 'enemy' and a 'criminal' also varied. ${ }^{129}$ However, there were no cases in the postwar LSSR, which remind us of the situation in the mid-1930s in the RSFSR, when loyal communists, with no 'bourgeois' or kulak or non-Bolshevik past, could be recognised as class enemies. The LSSR did not experience cleansing of the Lithuanian Communist Party. In Soviet Lithuania's case, most of the trials had a different logic: the 'criminal' was either a real opponent of the Soviet state, or an individual belonging to the 'enemy class' category of kulaks, byvshie liudi, or others.

Finally, when talking about crime in the LSSR, it is important to mention the fact that the Soviet authorities dealt with non-political crimes too. Many 'normal' crimes were investigated by the People's Courts, from the production of home-made vodka ${ }^{130}$ to violence and theft. ${ }^{131}$

It is nonetheless important to stress that the division between political and other types of criminals, were very significant in the Soviet system of prisons and camps. The Gulag system of the USSR in particular highlighted this division. As Mark Galeotti underlined, both types had different positions in the hierarchy of prisoners: 'As millions of political prisoners were rounded up and put to forced labour, the state began co-opting "criminal" criminals as enforcers, to keep the "political" in line'. ${ }^{132}$ When the Lithuanian prison system was included in the Soviet network, it took over the main features of the latter, the division between 'political' and 'criminal', and even some features of Gulag subcultures. The difference between 'political' and 'criminal' prisoners, according to the memoirs of a Lithuanian prisoner, was very strong and encouraged by the Gulag's administration. ${ }^{133}$

After the death of Stalin, the Soviet Lithuanian criminal justice system generally lost its former totalitarian character. The relative

${ }^{129}$ Applebaum, GULAG. A History, p. 6.

${ }^{130}$ The criminal file of the People's Court of the LSSR, LYA, f. V-145/40, ap. 1 , b. $391,1.1$.

${ }^{131}$ The criminal file of the People's Court of the LSSR, ibid., b. 2321, 1. 11.

${ }^{132}$ M. Galeotti, 'The Russian Mafiya: Economic Penetration at Home and Abroad', Economic Crime in Russia, p. 31; Lithuania in 1940-1991: the History of Occupied Lithuania, pp. 246-253.

${ }^{133}$ K. Lakickas, Kalinys Z-311 (Vilnius, 1994), p. 111. 
liberalisation of the penal system, as well as the changed concepts of crime and the criminal, played a huge role. All former patterns of Soviet criminal law and the activity of the criminal justice system, 'the material definition of crime', 'joint responsibility', prosecution for crimes committed when Soviet law did not function in the territory, or for social origin (the criminalisation of byvshie liudi and kulaks) were abolished from Soviet legal theory and legislation.

On 30 December 1954, the Supreme Council of the LSSR issued a decree aimed to supplement the Criminal Code of the RSFSR, used in the territory of the LSSR, with article No. 54-1. It implemented parole for prisoners who had served no less than two-thirds of their sentence, if there were evidences of their success in being 'corrected'. Between 1953 and 1960, punishments for many crimes which under Stalin were treated as 'especially dangerous' became softer. However, legal responsibility for a limited group of crimes, defined as 'especially dangerous', was made even stricter. On 21 May 1957, the Council of Ministers of the Lithuanian SSR announced a decree on the task to create a new criminal code for Soviet Lithuania. A commission was formed to fulfil this task. ${ }^{134}$

The new criminal code of Soviet Lithuania was finally adopted on 26 June 1961, and came into force on 1 September. The new criminal code stated that only actions and omissions defined in the code could be treated as crimes. ${ }^{135}$ So the main feature of Stalinist legislation, the principle of analogy, was eliminated, and the 'material definition of crime' together with it.

But the new criminal code lacked independence. For its architecture, the laws of the whole USSR, and especially the RSFSR, were used. ${ }^{136}$

Some old patterns were continued in legal practice, the work of the courts and processes of criminal investigation. It was especially evident in political cases. In political cases against Lithuanian dissidents, for instance, even the old definition of a criminal as a class enemy sometimes still functioned. There were cases when individuals and opponents of the Soviet system were criminalised, not only because of their recent activities, but also for 'counter-rev-

${ }^{134}$ Maksimaitis, Vansevičius, Lietuvos valstybès ir teisès istorija, pp. 276, 278-279.

${ }^{135}$ Ibid., Lietuvos Tarybu socialistiès respublikos baudžiamasis kodeksas (Vilnius, 1978), pp. 3, 8 .

${ }^{136}$ Maksimaitis, Vansevičius, Lietuvos valstybès ir teisès istorija, p. 279. 
olutionary activities' of the past: in the file of Antanas Gintautas Sakalauskas, who was prosecuted for anti-Soviet activity, we can find an entry made in 1974 with the accusation that this man 'in the past was punished according to Article 84 of the RSFSR penal Code for escaping to a foreign country' and had contacts with an 'illegal anti-Soviet organisation'. ${ }^{137}$

Sometimes even the old method, labelling criminals according to the category of class enemy, was applied even after the Stalinist period. Such was, for example, the case of Jonas Volungevičius, accused of writing 'a letter of anti-Soviet content', and the dissemination of 'anti-Soviet leaflets' in the period between 1965 and 1966. In the case, his family history was emphasised, and the fact that his father was sentenced in the 1940s for 'anti-Soviet activity' is taken seriously into consideration. ${ }^{138}$ So the indirect impression is formulated that a person of 'bad' social origin and a 'criminal' family is more likely to commit a crime.

Hence, as we see, at the level of the practice of law enforcement and law breaking, even some features of old Bolshevik revolutionary 'legal nihilism' were not forgotten, even in the 1940s, 1950s and later. This was especially true in the highest circles of the Soviet nomenclature. While in the Stalinist period many of them had been accused and punished for imagined crimes they never committed, for others, on the contrary, a high position in the nomenclature could ensure legal immunity (never officially expressed in documents, but common in practice), even in cases of serious crimes. In Lithuania, during 1940-1941, and from 1944, the LSSR Communist Party nomenclature even developed a separate system of 'party penalties'. So some members of the Communist Party nomenclature in the LSSR, even when violating Soviet law, did not come under the usual jurisdiction of Soviet courts, but were punished inside the Communist Party by a closed and secret inner punishment mechanism. ${ }^{139}$ Thus, some of the crimes they committed never became public until the collapse of the Soviet Union.

${ }^{137}$ The criminal files of Aloyzas Mackevičiaus, Vidmantas Povilionis, Izidoriaus Rudaitis, Gintautas Antanas Sakalauskas, Šarūnas Žukauskas, LYA, f. K-1, ap. 58, b. $47668 / 3$, t. $1,1.60$.

138 The criminal files of Jonas Volungevičius and Alvydas Petras Antanas Šeduikis, ibid., b. 47484/3, t. 1, 1. 119, 147, 148.

${ }^{139}$ M. Ėmužis, 'Partinès bausmès Sovietų Lietuvoje (XX a. penktasis-septintasis dešimtmečiai): tarp klientelizmo ir kolektyvizmo', Genocidas ir Rezistencija, no 2(38) (2015), pp. 68-85. 
All the above-mentioned cases demonstrate that legal practice could differ from the official definition of criminality in ideology, the public discourse and law, and that, even under strict imperial control, some local features at the level of law enforcement and law breaking could exist.

\section{Conclusions}

Bolshevik legal theory can be defined as 'legal nihilism'. It claimed that crime rates would decline in the process of the creation of a communist society; therefore, the law would soon not be needed. But in practice, the creation of the Soviet criminal justice system started very soon after the October Revolution.

The main concepts of Soviet criminal legislation and prototypes of institutions responsible for the investigation and punishment of crimes were developed during the period of the October Revolution and the Civil War. A crime was defined as an act or omission dangerous to the Soviet order and state, but not as an act or omission prohibited by the law. The Bolshevik penal codification embodied this logic using the 'material definition of crime' and the 'principle of analogy'. The concept of crime in Soviet legislation also embodied the dimension of collective responsibility, and made possible the criminalisation of activities carried out before Bolshevik law came into force.

The reform referred to as the 'restoration of law' in the mid-1930s changed the nihilist attitude towards the law with the legal theory of positivism. However, the main features of Bolshevik criminal legislation survived. In the field of institutions, some new actors were established, and some functions and names of already-existing ones changed, but the institutional network based on judicial (the Supreme Court and People's Courts) and extra-judicial institutions, as the main actors in the process of criminal prosecution, survived. Thus, the Stalinist period brought about some considerable changes and reforms, but did not transform the old Bolshevik system from its very core. On the contrary, this system was qualitatively suited to carrying out Stalin's terror, but had to be expanded in quantity (as, for instance, the network of the Gulag), and to be newly shaped ideologically and theoretically.

The criminal justice system model formulated during the early Bolshevik period was transferred to the Soviet 'colonies'. The 
LSSR adopted completely the legislation and the legal theory of the centre of the Soviet 'empire' (the RSFSR). But in the network of institutions and at the practical level of criminal prosecution, some local features existed.

Author Details

Monika Kareniauskaite is a $\mathrm{PhD}$ candidate at Vilnius University. She obtained her MA in history in 2012 at Vilnius University. She has worked as a researcher and senior historian in the Genocide and Resistance Research Centre of Lithuania, and as a research fellow at the University of St Gallen in the Department of Russian Culture and Society. In 2015, she was a scientific assistant at the Berlin-Hohenschönhausen memorial. Her research focuses on the law, jurisdiction and criminality in the Soviet Union, and the anti-communist opposition in Soviet Russia and Soviet Lithuania.

Address: Genocide and Resistance Research Centre of Lithuania, Didžioji g. 17/1, Vilnius LT-01128

E-mail: monika.kareniauskaite@gmail.com

\section{References}

AKERS, R.L., Criminological Theories: Introduction and Evaluation (London: Routledge, 1999).

ANDRIULIS, V., et. al., Lietuvos teisès istorija (Vilnius: Justitia, 2002).

ANUŠAUSKAS A., et al., Lietuva 1940-1990. Okupuotos Lietuvos istorija (Vilnius: Lietuvos gyventojų genocido ir rezistencijos tyrimo centras, 2007).

ANUŠAUSKAS A., et al., Lithuania in 1940-1991: the History of Occupied Lithuania, (Vilnius: Lietuvos gyventojų genocido ir rezistencijos tyrimo centras, 2015).

ANUŠAUSKAS, A., Teroras. 1940-1958 m. (Vilnius: Versus aureus, 2012).

APPlEBAUM, A., GULAG. A History (New York: Doubleday, 2003).

BÄCKMAN, J., 'The Hyperbola of Russian Crime and the Police Culture', in: Economic Crime in Russia, A.V. Ledeneva, M. Kurkchiyan (eds.) (The Hague, London, Boston: Kluwer Law International, 2000), pp. 257-274.

BERMAN, H.J., Justice in the USSR. An Interpretation of Soviet Law (Cambridge, London, 1987).

BERMAN, H.J., 'Principles of Soviet Criminal Law', in: The Yale Law Journal, vol 56, no 5, May (1947), pp. 803-836.

BOWRING, B., Law, Rights and Ideology in Russia. Landmarks in the destiny of a great power, (Abingdon, New York: Routledge, 2013). 
ESAKOV, G., 'The Russian Criminal Jury: Recent Developments, Practice, and Current Problems', in: The American Journal of Comparative Law, vol. 60 (2012), pp. 665-702.

ĖMUŽIS, M., 'Partinès bausmès Sovietų Lietuvoje (XX a. penktasis-septintasis dešimtmečiai): tarp klientelizmo ir kolektyvizmo', in: Genocidas ir Rezistencija, no 2(38) (2015), pp. 68-85.

FELDBRUGGE, F.J.M., 'Soviet Criminal Law. The Last Six Years', in: The Journal of Criminal Law, Criminology and Police Science, vol. 54, no 3, September (1963), pp. 249-266.

GAILIUS, B., Partizanai tada ir šiandien (Vilnius: Versus aureus, 2006).

GALEOTTI, M., 'The Russian Mafiya: Economic Penetration at Home and Abroad', in: Economic Crime in Russia, A. V. Ledeneva, M. Kurkchiyan (eds.) (The Hague, London, Boston: Kluwer Law International, 2000), pp. 31-42.

GLENDON, M.A., GORDON, M.W., OSAKWE, C., Vakaru teisès tradicijos (Vilnius: Pradai, 1993).

GREGORY, P.R., Terror by Quota: State Security from Lenin to Stalin (New Haven, London: Yale University Press, 2009).

GUINS, G.C., Soviet Law and Soviet Society (The Hague: Martinus Nijhoff, 1954).

HOSKING, G., Rulers and victims: the Russians in the Soviet Union (Cambridge, London: Harvard University Press, 2006).

INDRIŠIONIS, D., 'Mirties bausmė Lietuvos SSR 1950-1990 m.: teisiniai pagrindai ir periodizacija', in: Genocidas ir Rezistencija, no 1(39) (2016), pp. 65-80.

KIRALFY, A.K.R., 'Recent Legal Changes in the USSR', in: Soviet Studies, vol. 9, no 1, July (1957), pp. 1-19.

LAPPENA, I., Soviet Penal Policy (Denmark, 2000).

LILLY, J.R., CULlEN, F.T., BALL, R.A., Criminological Theory: Context and Consequences (Thousand Oaks, California: SAGE Publications, 2011).

MAKSIMAITIS M., VANSEVIČIUS S., Lietuvos valstybès ir teisès istorija (Vilnius: Justitia, 1997).

OSTROUKH, A., 'Russian Society and its Civil Codes: A Long Way to Civilian Civil Law', in: Journal of Civil Law Studies, vol. 6, issue 1, summer (2013), pp. 372-400.

PIPES, R., Russia Under the Bolshevik Regime (New York: Vintage, 1995).

ROSENTHAL, B.G., New Myth, New World: From Nietzsche to Stalinism (University Park, Pennsylvania: The Penn State University Press, 2002).

SAGATIENĖ, D., Sovietiniai bendrosios kompetencijos teismai Lietuvoje 1940-1941 ir 1944-1953 metais, Daktaro disertacija (Vilnius: MRU, 2013). 
SAGATIENĖ, D., 'Sovietinių teismų atkūrimas ir raida Lietuvoje 1944-1956 metais’, in: Socialiniu Moksly Studijos / Societal Studies, no 5(1), (2013), pp. 193-213.

SEBAG MONTEFIORE, S., Der Junge Stalin (Frankfurt am Mein: S. Fischer Verlag, 2007).

SOLOMON, P.H. Jr., Soviet Criminal Justice under Stalin (Cambridge: Cambridge University Press, 1996).

SNYDER, T., Bloodlands: Europe between Hitler and Stalin (New York: Basic Books, 2010).

STARKAUSKAS, J., Čekistinè kariuomenè Lietuvoje 1944-1953 metais: NKVD-MVD-MGB kariuomene partizaninio karo laikotarpiu (Vilnius: Lietuvos gyventojų genocido ir rezidencijos tyrimo centras, 1998).

SURHONE, L.M., TENNOE, M.T., HENSSONOW, S.F., Procurator General of the Soviet Union (Saarbrücken: Betascript Publishing, 2011).

ŠAPOKA, G., 'Sovietinès Lietuvos baudžiamosios teisès vertinimas lietuvių teisininkų išeivių darbuose', in: Jurisprudencija, no 18(2) (2011), pp. 455-465.

VAN DEN BERG, G.P., 'The Soviet Union and the Death Penalty', in: Soviet Studies, vol. 35, no 2, Apr. (1983), pp. 154-174.

VIOLA, L., 'The Second Coming: Class Enemies in the Soviet Countryside, 1927-1935', in: Stalinist Terror. New Perspectives, J.A. Getty, R.T. Manning (eds.) (Cambridge, 1993), pp. 65-98.

ŽIEMELIS, V., 'Lietuvos prokuratūros pertvarkymo ị sovietinę prokuratūrą raida 1940-1941 metais', in: Jurisprudencija, no. 12(102) (2007), pp. 16-21.

ВЕРТ, Н., Террор и безпорядок. Сталинизм как система (Москва: РОССПЭН, 2010).

Сталинизм в советской провинщии: 1937-1938 г2. Массовая операциия на основе приказа № 00447, сост.: М. Юнге, Б. Бонвеч, Р. Биннер (Москва: РОССПЭН, 2009). 


\title{
KRIMINALINĖS TEISĖS SISTEMA SOVIETŲ RUSIJOJE IR SSRS: IŠTAKOS, FORMAVIMASIS, BŪKLE், STALINISTINIO LAIKOTARPIO PERMAINOS IR ITGYVENDINIMAS LIETUVOS SSR
}

Santrauka

\author{
MONIKA KARENIAUSKAITE
}

Straipsnyje analizuojama Sovietų Rusijoje bolševikų suformuota ir SSRS įtvirtinta nusikaltimo samprata, čia veikusios baudžiamosios teisès atsiradimo aplinkybès, jos struktūra bei ịkūnijama logika, taip pat tiriamas sovietinès baudžiamojo persekiojimo sistemos modelis, struktūra bei veikimo mechanizmas. Ši sovietinè nusikaltimo samprata, baudžiamoji teisè ir visa baudžiamojo persekiojimo sistema buvo pradètos diegti dar $1917 \mathrm{~m}$. Rusijos revoliucijos bei pilietinio karo metais, ịtvirtintos vykdant Naujają ekonominę politiką bei kolektyvizaciją, Stalino ir Andrejaus Višinskio ketvirtojo XX a. dešimtmečio viduryje šiek tiek instituciškai reformuotos ir galiausiai, po Lietuvos okupacijos ir aneksijos, imtos diegti šioje naujoje Sovietu Sajungos kolonijoje. Taigi, straipsniu taip pat siekiama atskleisti, kaip sovietine baudžiamojo persekiojimo sistema buvo diegiama Lietuvos okupacijos bei kolonizacijos sąlygomis. Tyrimas atskleidè, kad ikirevoliucinès bolševikų patirties, tradicinio imperinės Rusijos valstiečių mentaliteto paveikta ir marksizmo postulatų generuojama ankstyvoji bolševikų baudžiamojo persekiojimo sistema ir teisès normos jau turèjo daugelį savybių, radikaliai nekeistų ir nekitusių iki pat Stalino mirties ir tinkamų masinèms represijoms vykdyti. Sovietų Rusijos baudžiamasis kodeksas nusikaltimu laikẻ kiekvieną veiką ar neveikimą, pripažintą pavojingu sovietinei valstybei ar santvarkai, bet ne veiką ar neveikimą, uždraustus ịstatymo. Praktiškai šią logiką ịtvirtino vadinamasis analogijos principas, leidęs nesant tinkamo įstatymo taikyti bet kuri kitą panašų baudžiamojo kodekso straipsnị. 1926 m. Sovietų Rusijos baudžiamasis kodeksas, rėmęsis revoliucijos ir pilietinio karo metais išplètotomis bolševikų teisinèmis normomis, ketvirtojo XX a. dešimtmečio reformos metu nebuvo pakeistas ir galiojo iki pat Stalino mirties. Tokia baudžiamoji sistema, beveik be pakeitimų, buvo perkelta ị Lietuvos SSR. Sovietų Lietuvoje beveik nebūta teisinio savarankiškumo - neturèta net atskiro baudžiamojo kodekso. Čia veikè 1926 m. Sovietų Rusijos kodeksas. LSSR teisinè sistema taip pat buvo įtraukta ị visos Sovietų Sajungos sistemą, o sajungos lygiu priimti ịstatymai turèjo prioritetą respublikinių atžvilgiu. Vis dèlto Lietuvos SSR kolonizacijos procesas baudžiamojo persekiojimo srityje strigo. Nors sovietiniai įstatymai buvo priimti, o institucijos ịkurtos, praktinị baudžiamajj persekiojimą ir sovietinès jurisdikcijos ịsigalējimą apsunkino aktyvi ginkluotoji rezistencija. O teismų darbui trukde pakankamai išsilavinusių ir okupaciniam režimui lojalių darbuotojų stygius. 